\title{
Bone Mineral Density in Jamaican Black Women after Hysterectomy and Bilateral Oophorectomy: An Observational Study
}

\author{
HM Fletcher ${ }^{1}$, F Bennett ${ }^{2}$, D Simms-Stewart ${ }^{1}$, M Reid ${ }^{3}$, NP Williams ${ }^{2}$, GH Wharfe ${ }^{2}$
}

\begin{abstract}
Objective: To see if black Jamaican postmenopausal women who had hysterectomy were at increased risk of osteoporosis. To assess the risk of osteoporosis in hysterectomized Jamaican postmenopausal patients.

Method: We reviewed 809 women (403 hysterectomized and 406 controls) for cardiovascular disease risk. We did a demographic history and examination looking at blood pressure, waist hip ratio and body mass index and investigations done included fasting blood glucose and total and high density lipoprotein (HDL) cholesterol. We also measured bone density at the heel in all women using the Achilles ultrasound bone densitometer looking at T-score and Z-score.

Results: There was a significant association of hysterectomy status and bone mineral density (BMD) status with a smaller than expected proportion of women with osteoporosis in the hysterectomy group $\left(\chi^{2}=18.4 ; \mathrm{p}=0.001\right)$. The mean T-score was significantly higher in the hysterectomized women, adjusting for age, waist circumference and sociodemographic factors. The relationship between the various predictors and BMD was explored by stepwise regression modelling. The factors that were significantly related to low BMD were hysterectomy status, age, waist circumference and being employed.

Conclusion: Hysterectomy was not found to be a significant risk factor for osteoporosis. The osteoporosis risk among menopausal women in Jamaica appears to be due to other risk factors which probably existed prior to the operation.
\end{abstract}

Keywords: Hysterectomy disease risk, osteoporosis disease risk

\section{Densidad Mineral Ósea en Mujeres Negras Jamaicanas después de Histerectomía y Ooforectomía Bilateral: Un Estudio Observacional}

HM Fletcher ${ }^{1}$, F Bennett ${ }^{2}$, D Simms-Stewart ${ }^{1}$, M Reid ${ }^{3}$, NP Williams ${ }^{2}$, GH Wharfe ${ }^{2}$

\begin{abstract}
RESUMEN
Objetivo: Determinar si mujeres negras jamaicanas postmenopáusicas sometidas a histerectomía corrían mayor riesgo de osteoporosis. Evaluar el riesgo de osteoporosis en pacientes jamaicanas postmenopáusicas histerectomizadas.

Método: Se examinaron 809 mujeres (403 histerectomizadas y 406 controles) para evaluar el riesgo de enfermedad cardiovascular. Hicimos una historia demográfica y un examen para obtener información sobre la presión arterial, el índice cintura/cadera ratio, y el indice de masa corporal. Asimismo, realizamos investigaciones que incluyeron pruebas de glucemia en ayunas, colesterol total, y colesterol de lipoproteinas de alta densidad (HDL). También medimos la densidad ósea en el talón de todas las mujeres, usando el densitómetro óseo ultrasónico modelo Achilles para obtener el T-score y el Z-score. Resultados: Hubo una asociación significativa entre el estado de histerectomía y el estado de la densidad mineral ósea (DMO) con una proporción de mujeres con osteoporosis en el grupo de histerectomía $(\chi 2=18.4 ; \mathrm{p}=0,001)$ más pequeña de lo esperada. El T-score promedio fue significativamente mayor en las mujeres histerectomizadas, ajustando por edad, circunferencia de la cintura y factores sociodemográficos. La relación entre los distintos factores predictivos y DMO fue
\end{abstract}

From: ${ }^{1}$ Department of Obstetrics and Gynaecology, ${ }^{2}$ Department of Pathology and ${ }^{3}$ Tropical Metabolism Research Unit, The University of the West Indies, Kingston 7, Jamaica.
Correspondence: Professor H Fletcher, Department of Obstetrics and Gynecology, The University of the West Indies, Kingston 7, Jamaica. Email: horace.fletcher@uwimona.edu.jm 
explorada mediante regresión gradual stepwise modelado. Los factores que estuvieron significativamente relacionados con baja DMO fueron estado histerectomía, edad, circunferencia de la cintura y siendo empleado.

Conclusión: Se halló que la histerectomía no es un factor de riesgo significativo para la osteoporosis. El riesgo de osteoporosis entre las mujeres menopáusicas de Jamaica parece deberse a otros factores de riesgo que probablemente existian antes de la operación.

Palabras claves: Riesgo de enfermedad por histerectomía, riesgo de osteoporosis

West Indian Med J 2013; 62 (7): 594

\section{INTRODUCTION}

Osteoporosis risk is usually attributed to ethnicity (Caucasians more than Negroids), lack of exercise, lack of exposure to sunlight and low vitamin $\mathrm{D}$ intake. The older one gets, the greater the risk and many of the risk factors are therefore more prevalent after menopause. Other risk factors for osteoporosis include social habits such as smoking and alcohol use, a history of hip fracture in a parent, thinness (as defined by weight $<57.7 \mathrm{~kg}$ or body mass index (BMI) $<21 \mathrm{~kg} / \mathrm{m}^{2}$ ), the use of glucocorticoid medications for more than three months and oestrogen deficiency from surgical castration (1). Even amongst Caucasian women, those with darker skin were noted to have better bone density, possibly related to sunlight exposure times and vitamin D status (2). Women of African ethnicity generally have less risk of fractures and higher bone mineral density (BMD) compared with Caucasian women (3). Jamaica is a tropical island with geographic coordinates of $18^{\circ} 15^{\prime}$ North and $77^{\circ} 30^{\prime}$ 'West with approximately 3002 sunshine hours annually and 8.2 sunlight hours on average per day. Thus, with $>95 \%$ of the population of African descent, Jamaican women living in Jamaica would be expected to have low prevalence of low BMD. However, this has not yet been assessed in a systematic manner by Jamaican researchers.

Because hysterectomy is common in our setting, we decided to see how frequent this was seen as a complication of this operation. Although falls in the elderly as a risk for fracture appear to be common in Jamaica (4), nothing has been written about osteoporosis in elderly women in Jamaica. This is despite the fact that $73 \%$ of patients admitted to the University Hospital of the West Indies (UHWI) who had hip fractures were women and $78 \%$ of the patients who had fractures were over age 65 years (5).

In Jamaica, hysterectomy is very common, because of the high incidence of large uterine fibroids; bilateral oophorectomy is also a common practice in women over age 45 years and hormone replacement therapy is only prescribed to women with symptoms of the menopause. Whether hysterectomy with or without bilateral oophorectomy affects BMD in Jamaican women is unclear.

We aimed to assess the impact of hysterectomy among black Jamaican women in a country where it is believed osteoporosis is not common. However, we wished to test the hypothesis that among Jamaican women, hysterectomy is associated with increased odds of having osteoporosis and osteopaenia compared to controls.

As part of cardiovascular disease (CVD) after hysterectomy study (6), we also measured BMD using a peripheral ultrasonic method. Screening for low bone density is now recognized to be best done with dual energy X-ray absorptiometry (DEXA), however, the use of Calcaneal ultrasonography has been found to be inexpensive compared to DEXA while giving a reasonably good prediction of fracture risk in Caucasians and black women $(7-10)$.

Our cardiovascular study reported on differences in cardiovascular risks between women who underwent hysterectomy and age matched controls who did not. Using this data set, we now report on the differences in BMD between the hysterectomy group and non-hysterectomy group and whether hysterectomy was an independent risk factor for low $\mathrm{BMD}$, adjusting for traditional risk factor of age and nutritional status as assessed by anthropometry.

\section{SUBJECTS AND METHODS}

This was a cross-sectional observational study among women who had had hysterectomy with or without bilateral oophorectomy compared to age-matched women who had not had these surgical procedures. The primary outcome of cardiovascular risks has been reported (6). Briefly, women were eligible for the study if they had hysterectomy with and without bilateral oophorectomy before menopause (artificial menopause) over age 40 years. These women were compared with a group of a similar age and social status that had not had hysterectomy and oophorectomy (natural menopause).

The clinical records of women who had hysterectomy from 1980 to 2000 at the UHWI were reviewed. The addresses of the hysterectomized women were obtained and eligible women were invited by mail to participate in the study. In addition, women were invited to participate from health fairs as well as the use of posters advertising the study. Non-hysterectomized controls were recruited from among the relatives of patients from the gynaecology clinic and from health fairs.

Recruited women had their assessments done at the Gynaecology Department, UHWI, Mona, after an overnight fast. These included the completion of an intervieweradministered questionnaire to obtain sociodemographic data, 
lifestyle practices including cigarette and alcohol use and past medical history information such as cancer or steroid use. For women who had hysterectomy, data on oophorectomy status were corroborated by pathology records where possible. This was followed by anthropometry, blood pressure, venepuncture for fasting glucose and lipids as previously described. For convenience, the anthropometric and BMD measurements are described below.

Weight was recorded to the nearest $0.1 \mathrm{~kg}$ using a balance scale (Delta meter, mechanical balance scale, USA) after each participant removed shoes and outer clothes. Height was measured to the nearest $0.1 \mathrm{~cm}$ using standard technique on a stadiometer. Waist and hip circumferences were measured to the nearest centimetre using anthropometric tape according to standard techniques. Body mass index (BMI) was computed as weight in kilograms per metre squared, and waist-hip ratio as ratio of waist measurement in $\mathrm{cm}$ to hip measurement in $\mathrm{cm}$. Anthropometry was done by either a registered nurse, a doctor or by a research assistant who had been taught to do the procedures.

Bone density was measured using an Achilles heel ultrasonic bone densitometer (General Electric, USA). This machine was calibrated to read for age, gender and ethnicity and measurements were always done after the machine had passed a quality assurance test. Both the T-score and the Zscores were done. The T-score, which compares a patient's bone density with that of a young, white female, is considered positive for osteoporosis if it is less than or equal to -2.5. The Z-score is a comparison of the patient's bone density with a standard patient matched for age, race and ethnicity.

The data were entered into SPSS, verified and cleaned. The Stata statistical software for Windows, version 9 (Stata Corp, College Station, TX) was used for the analysis. The sample consisted initially of two groups, a group who did not have hysterectomy (Control) and a group of women who had hysterectomy (Hysgroup). The data were subsequently divided into normal BMD, osteopaenia and osteoporosis groups based on World Health Organization (WHO) T-score criteria. Results are expressed as counts, medians with ranges or means with standard deviations as appropriate. Independent $t$-test or analysis or variance (ANOVA) was used to compare means of continuous variables whilst the Mann-Whitney or the Kruskal-Wallis tests were used to compare distributions of skewed continuous variables between groups. Associations between categorical variables and groups were tested with Chi-squared statistic.

Multiple variable linear regressions were used to explore differences between the groups for BMD, adjusting for sociodemographic, lifestyle and anthropometry predictors. Stepwise regression modelling strategy was used to determine the parsimonious model predicting BMD from data. In this approach, hysterectomy status and age were forced entered in the model. For the other candidate variables (sociodemographic, lifestyle and anthropometry), the criteria for entry was $p<0.05$ and $p>0.1$ for removal.

The study proposal and the instruments were reviewed and approved by the University Hospital of the West Indies/University of the West Indies/Faculty of Medical Sciences Ethics Committee. The women were given an explanation of the purpose of the study and all participants gave written informed consent.

\section{RESULTS}

We recruited a total of 809 postmenopausal Afro-Jamaican women of which 406 (50.19\%) had no surgery (Controls) and 403 had hysterectomy (Hysgroup), with 252 having had total abdominal hysterectomy (TAH) [31.2\%] and $151 \mathrm{TAH}$ with bilateral salpingo-oophorectomy (BSO) $[18.7 \%]$. Bone mineral density measurements were performed on 761 women, 370 in the Control group and 391 in the Hysgroup. However, the sample for data analysis consisted of 629 as 132 women ( 74 women from the control group and 58 women from the hysterectomy group) had missing data on covariates (Fig. 1).

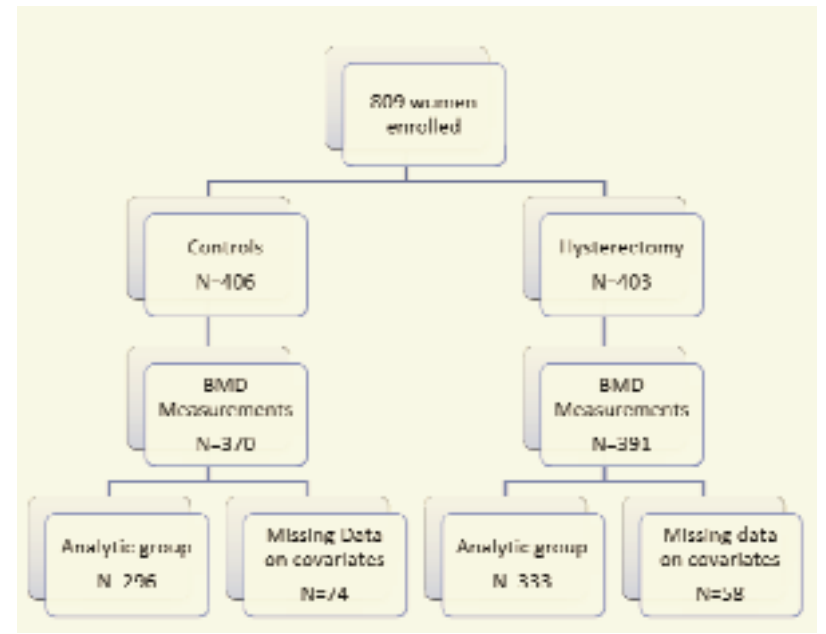

Fig. 1: Flow chart of enrolled subjects in study.

Most (412;65\%) of the analytic sample had normal bone density of which 169 were in the Control group and 243 in the Hysgroup. There were 187 women (30\% of analytic sample) with osteopaenia of which 107 were in the Control group and 80 in the Hysgroup. Thirty women or $5 \%$ of the analytic sample had osteoporosis with $20(67 \%)$ in the Control group and 10 (33\%) in the Hysgroup. There was a significant association of hysterectomy status and BMD status with a smaller than expected proportion of women with osteoporosis in the hysterectomy group $\left[\chi^{2}=18.4 ; p<\right.$ $=0.001]$ (Table 1). There was no difference in mean age, weight, height, BMI, hip circumference, waist-hip ratio, waist-triceps ratio, $\mathrm{T}$-scores and Z-scores between Controls and Hysgroup. However, mean waist circum-ference was significantly higher in the controls compared with Hysgroup (91.2 \pm 13.4 vs $89.6 \pm 11.7), p=0.0006$. In contrast, there were significant main effects of BMD status for age, weight, 
Table 1: Clinical and anthropometric characteristics of sample by hysterectomy group and bone mineral density (BMD) group

\begin{tabular}{|c|c|c|c|c|c|c|c|c|c|}
\hline $\begin{array}{l}\text { Clinical } \\
\text { characteristics }\end{array}$ & \multicolumn{3}{|c|}{ Control } & \multicolumn{3}{|c|}{ Hysterectomy } & \multirow{2}{*}{$\begin{array}{c}\text { Main } \\
\text { effect } \\
\text { hysterec- } \\
\text { tomy }\end{array}$} & \multirow{2}{*}{$\begin{array}{l}\text { Main } \\
\text { effect } \\
\text { BMD } \\
\text { status }\end{array}$} & \multirow{2}{*}{$\begin{array}{c}\text { Interaction } \\
\text { effect } \\
\text { hysterectomy } \\
\text { x BMD } \\
\text { status }\end{array}$} \\
\hline $\begin{array}{l}\text { Variables } \\
\mathrm{n}\end{array}$ & $\begin{array}{l}\text { Normal } \\
169\end{array}$ & $\begin{array}{l}\text { Osteopaenia } \\
107\end{array}$ & $\begin{array}{l}\text { Osteoporosis } \\
20\end{array}$ & $\begin{array}{l}\text { Normal } \\
243\end{array}$ & $\begin{array}{c}\text { Osteopaenia } \\
80\end{array}$ & $\begin{array}{c}\text { Osteoporosis } \\
10\end{array}$ & & & \\
\hline Age (years) & $56.1 \pm 8.1$ & $62.3 \pm 10.4$ & $60.9 \pm 9.9$ & $57 \pm 8.5$ & $58.8 \pm 8.3$ & $63.9 \pm 9.1$ & 0.3 & $<0.001$ & $<0.014$ \\
\hline Weight (kg) & $76.8 \pm 16$ & $68.5 \pm 15.5$ & $77.2 \pm 26$ & $75.3 \pm 14.5$ & $69 \pm 14.1$ & $78.3 \pm 21.2$ & 0.3 & $<0.001$ & 0.7 \\
\hline Height $(\mathrm{cm})$ & $160.5 \pm 5.9$ & $158.6 \pm 6.4$ & $159.1 \pm 7.7$ & $159.6 \pm 7.1$ & $159.3 \pm 5.7$ & $160.1 \pm 8.4$ & 0.1 & $<0.05$ & 0.3 \\
\hline Body mass index (kg) & $29.8 \pm 5.8$ & $27.2 \pm 5.8$ & $30.2 \pm 9.1$ & $29.6 \pm 5.6$ & $27.2 \pm 5.2$ & $30.3 \pm 6.5$ & 0.6 & $<0.008$ & 1.0 \\
\hline Waist circumference $(\mathrm{cm})$ & $92.8 \pm 12.4$ & $88.1 \pm 13$ & $93.8 \pm 20.4$ & $90.7 \pm 12$ & $86.3 \pm 10.1$ & $94.8 \pm 15$ & $<0.05$ & $<0.006$ & 0.7 \\
\hline Hip circumference $(\mathrm{cm})$ & $107.2 \pm 11.2$ & $101.5 \pm 10.6$ & $106.7 \pm 17.6$ & $106 \pm 10.4$ & $101.6 \pm 9.8$ & $107.2 \pm 12.4$ & 0.2 & $<0.001$ & 0.7 \\
\hline Waist-hip ratio & $0.9 \pm 0.1$ & $0.9 \pm 0.1$ & $0.9 \pm 0.1$ & $0.9 \pm 0.1$ & $0.8 \pm 0.1$ & $0.9 \pm 0.1$ & 0.1 & 1.0 & 0.6 \\
\hline Waist-triceps ratio & $0.6 \pm 0.1$ & $0.6 \pm 0.1$ & $0.6 \pm 0.1$ & $0.6 \pm 0.1$ & $0.5 \pm 0.1$ & $0.6 \pm 0.1$ & 0.1 & $<0.05$ & 0.8 \\
\hline T-score & $0.2 \pm 1.1$ & $-1.6 \pm 0.5$ & $-3.3 \pm 0.6$ & $0.2 \pm 0.9$ & $-1.5 \pm 0.4$ & $-3.3 \pm 0.6$ & 0.5 & $<0.0001$ & 1.0 \\
\hline Z-score & $1.1 \pm 1.1$ & $-0.3 \pm 0.6$ & $-1.9 \pm 1.4$ & $1.3 \pm 1$ & $-0.4 \pm 0.7$ & $-1.9 \pm 0.8$ & $0.13<$ & $<0.0001$ & 0.7 \\
\hline
\end{tabular}

height, BMI, waist and hip circumferences as well as waisttriceps ratio.

There were no significant associations between marital status, post-secondary school training, employment, exercise status, sexual activity, smoking, alcohol use, history of hip/ wrist fracture and history of maternal fractures and hysterectomy status (Table 2). However, being employed was signifi-

Table 2: Sociodemographic characteristics of sample by hysterectomy group and bone mineral density (BMD) group

\begin{tabular}{|c|c|c|c|c|c|c|c|c|c|}
\hline \multirow{2}{*}{$\begin{array}{l}\text { Sociodemographic } \\
\text { variables }\end{array}$} & \multicolumn{3}{|c|}{ Control } & \multicolumn{3}{|c|}{ Hysterectomy } & \multirow{2}{*}{$\begin{array}{c}\text { Main } \\
\text { effect } \\
\text { hysterec- } \\
\text { tomy }\end{array}$} & \multirow{2}{*}{$\begin{array}{l}\text { Main } \\
\text { effect } \\
\text { BMD } \\
\text { status }\end{array}$} & \multirow{2}{*}{$\begin{array}{c}\text { Interaction } \\
\text { effect } \\
\text { hysterectomy } \\
\text { x BMD } \\
\text { status }\end{array}$} \\
\hline & Normal & Osteopaenia & Osteoporosis & Normal & Osteopaenia & Osteoporosis & & & \\
\hline $\mathrm{n}$ & 169 & 107 & 20 & 243 & 80 & 10 & $0.001^{*}$ & - & - \\
\hline Marital status & & & & & & & 0.6 & 0.5 & 0.027 \\
\hline Married & 71 & 53 & 9 & 108 & 30 & 9 & & & \\
\hline $\begin{array}{l}\text { Single/divorced/ } \\
\text { separated }\end{array}$ & 98 & 54 & 11 & 135 & 50 & 1 & 0.07 & 0.4 & 0.8 \\
\hline Post-secondary school training & & & & & & & & & \\
\hline No & 122 & 85 & 14 & 155 & 55 & 5 & & & \\
\hline Yes & 47 & 22 & 6 & 88 & 25 & 5 & & & \\
\hline Employment & & & & & & & 0.2 & 0.009 & 0.3 \\
\hline No & 66 & 62 & 10 & 79 & 38 & 7 & & & \\
\hline Yes & 103 & 45 & 10 & 164 & 42 & 3 & & & \\
\hline Exercise & & & & & & & 0.9 & 0.3 & 0.1 \\
\hline No & 71 & 35 & 9 & 103 & 38 & 3 & & & \\
\hline Yes & 98 & 72 & 11 & 140 & 42 & 7 & & & \\
\hline Sexually active & & & & & & & 0.7 & 0.1 & 0.2 \\
\hline No & 94 & 72 & 13 & 140 & 57 & 3 & & & \\
\hline Yes & 75 & 35 & 7 & 103 & 23 & 7 & & & \\
\hline Ever smoke & & & & & & & 0.6 & 0.3 & 0.7 \\
\hline No & 149 & 88 & 16 & 218 & 71 & 9 & & & \\
\hline Yes & 20 & 19 & 4 & 25 & 9 & 1 & & & \\
\hline Ever drink alcohol & & & & & & & 0.2 & 0.2 & 0.6 \\
\hline No & 125 & 89 & 16 & 193 & 65 & 8 & & & \\
\hline Yes & 44 & 18 & 4 & 50 & 15 & 2 & & & \\
\hline History of hip/wrist fracture & & & & & & & 0.7 & 0.5 & 0.2 \\
\hline No & 164 & 102 & 20 & 24 & 79 & 10 & & & \\
\hline Yes & 5 & 5 & 0 & 9 & 1 & 0 & & & \\
\hline History of maternal fracture & & & & & & & 0.1 & 0.2 & 0.08 \\
\hline No & 168 & 103 & 19 & 236 & 79 & 10 & & & \\
\hline Yes & 1 & 4 & 1 & 7 & 1 & & & & \\
\hline
\end{tabular}


cantly associated with BMD status. Within the Hysgroup, there was no association between oophorectomy status and BMD status (Table 3).

Table 3: Relationship between bone mineral density group (BMD) and oophorectomy status

\begin{tabular}{lccr}
\hline BMD group & $\begin{array}{c}\text { At least one ovary } \\
\text { retained }\end{array}$ & $\begin{array}{c}\text { bilateral } \\
\text { oophorectomy }\end{array}$ & Total \\
\hline Normal & 145 & 98 & 243 \\
Osteopaenia & 45 & 35 & 80 \\
Osteoporosis & 5 & 5 & 10 \\
Total & 195 & 138 & 333 \\
\hline
\end{tabular}

Pearson $\mathrm{Chi}^{2}(2)=0.6014 \quad \operatorname{Pr}=0.740$

The mean T-score was significantly higher in the Hysgroup adjusting for age, waist circumference and sociodemographic factors (Fig. 2). The relationship between

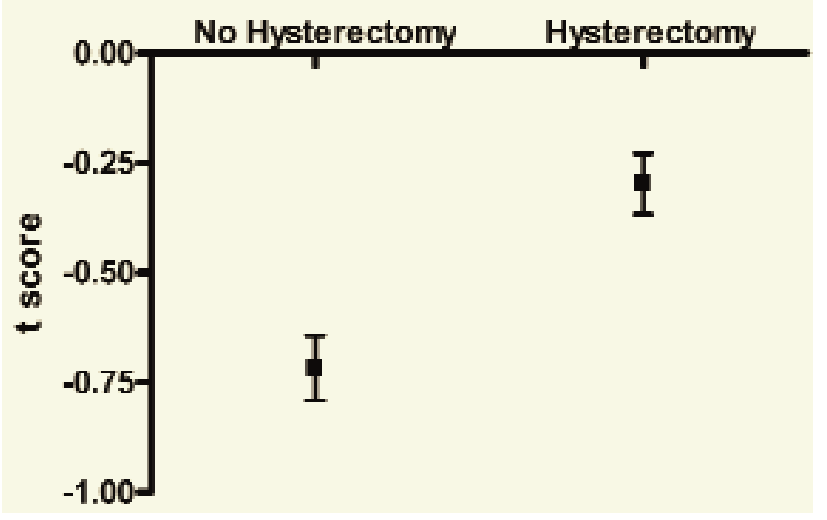

Fig 2: Mean T-score adjusted for age, waist circumference and sociodemographic factors.

the various predictors and BMD were explored by stepwise regression modelling. The factors that were significantly related to low BMD were hysterectomy status, age, waist circumference and being employed (Table 4).

Table 4: Regression model predicting T-score from data

\begin{tabular}{lccrc}
\hline Variables & Coefficient & $p$-value & $\begin{array}{c}\text { Lower } \\
\mathbf{9 5 \%} \text { CI }\end{array}$ & $\begin{array}{c}\text { Upper } \\
\mathbf{9 5 \%} \text { CI }\end{array}$ \\
\hline Hysterectomy & 0.36 & 0.001 & 0.17 & 0.56 \\
Age (years) & -0.03 & 0.001 & -0.04 & -0.02 \\
Waist (cm) & 0.01 & 0.03 & 0.00 & 0.02 \\
History of mother with & & & & \\
fracture & -0.62 & 0.07 & -1.29 & 0.05 \\
Employed & 0.31 & 0.01 & 0.10 & 0.53 \\
Constant & 0.17 & 0.75 & -0.87 & 1.21 \\
\hline
\end{tabular}

\section{DISCUSSION}

As expected, the presence of osteopaenia and osteoporosis in the overall cohort was similar to rates found in African
American women and lower than that found in Caucasian populations. From 1988-94, estimates indicated that $13-18 \%$ had osteoporosis and $37-50 \%$, or $13-17$ million, had osteopaenia (11). In 2005-2006, 49\% of older US women had osteopaenia and $10 \%$ had osteoporosis at the femoral neck (12). Prevalences have been said to be 1.3-2.4 times higher in white women compared to black women (13). The findings in this study of osteopaenia in $28.4 \%$ and osteoporosis in $5.5 \%$ in the overall cohort are lower than reported in US studies for white populations. However, the rates in the controls (31.9\% osteopaenia and $6.7 \%$ osteoporosis) were higher than that found in the women who had hysterectomy (24.6\% osteopaenia and $4.26 \%$ osteoporosis) and/or bilateral oophorectomy but were similar to that of another US study [39.6\% osteopaenia and 7.2\% osteoporosis done in 200160 postmenopausal women aged $>50$ years and $90 \%$ white (14)]. The lower rates in hysterectomized women were an unexpected finding as it was expected that hysterectomy and oophorectomy would have resulted in premature loss of oestrogen with resultant increased bone loss. In previous reports, other authors have described loss of ovarian function after hysterectomy even when the ovaries have not been removed $(15,16)$. Others have pointed out that the impact of ovarian removal is more significant when the ovaries are removed before age 45 years (17). However, other authors are now advocating leaving the ovaries in situ at hysterectomy even after this age as they claim that the risks of ovarian cancer are low (5\%) and the risks from ovarian failure are high (16).

In a previous paper in the same cohort, we found that the hysterectomized women also had better cardiovascular function after hysterectomy compared to controls and we postulated that this was probably due to the fact that most of the patients had hysterectomy for uterine fibroids, an oestrogen dependent condition (6). The same explanation therefore obtains for better bone density in these patients and helps to cement our postulate. This phenomenon has also been described in another population by others who also found that bone density was better in women who had hysterectomy for uterine fibroids compared to controls. They also postulated that the presence of fibroids may indicate more oestrogen exposure than controls without fibroids. They also found that there were less fractures in the hysterectomized patients compared with those without leiomyomas (18).

Low bone density is now recognized as the most important predictor of fracture risk in Caucasian women (19, 20). This has also been examined in other populations of African origin and the risks appear to be very high and underreported (21).

In this study we sought to determine whether there were differences in BMD by hysterectomy status as well as sociodemographic, lifestyle and anthropometry predictors of BMD in Jamaican women. We report that BMD was significantly higher in women with hysterectomy compared with controls and that the significant predictors of BMD were age 
(older women as expected being at greater risk), waist circumference (greater circumference at greater risk, suggests less exercise) and being employed (which is harder to explain but may also be related to diet and exercise patterns).

These are all factors that are well described and are all modifiable (22). In a recent Scottish study, regression analysis showed that body weight was the strongest predictor of BMD in women, accounting for $16.4 \%$ of the variance in spine BMD and $8.4 \%$ of the variance at the hip. Other significant predictors were genotype $(3.8 \%)$, vitamin D intake (3.4\%) and carbohydrate intake (1.6\%). Physical activity was the strongest predictor of BMD in men, accounting for $6.7 \%$ of the variance. Other significant predictors were body weight (5\%), genotype (2.8\%) and alcohol intake [2\%] (23).

This paper has shown that osteoporosis is relatively common in Jamaican postmenopausal women and although much emphasis has been placed on prevention of falls in other papers $(4,5)$, we wish to suggest that other strategies also need to be emphasized to reduce the burden of osteoporosis and thus help to reduce the risks of fractures in postmenopausal women in Jamaica. Some of these strategies include improvements in diet (higher vitamin D and calcium intake), increased exercise and screening and treatment of osteoporosis (22).

The present study does not support the routine use of oestrogen replacement in women who had uterine fibroids, post hysterectomy to prevent osteoporosis. This is of great significance, bearing in mind the risks of hormone replacement such as breast cancer, the leading cause of cancer in Jamaican women (24).

\section{ACKNOWLEDGEMENTS}

The study was supported by a grant from the Principal of the Mona Campus, The University of the West Indies, New Initiative funding.

\section{REFERENCES}

1. North American Menopause Society. Management of osteoporosis in postmenopausal women: 2006 position statement of The North American Menopause Society. Menopause 2006; 13: 340-67; quiz 3689.

2. May H, Murphy S, Khaw KT. Bone mineral density and its relationship to skin colour in Caucasian females. Eur J Clin Invest 1995; 25: 85-9.

3. Hochberg MC. Racial differences in bone strength. Asia Pac J Clin Nutr 2008; 17 (Suppl 1): 135-7.

4. James K, Eldemire-Shearer D, Gouldbourne J, Morris C. Falls and fall prevention in the elderly: the Jamaican perspective. West Indian Med J 2007; 56: 534-9.

5. Williams-Johnson JA, Wilks RJ, McDonald AH. Falls: a modifiable risk factor for the occurrence of hip fractures in the elderly. West Indian Med J 2004; 53: 238-41.

6. Fletcher HM, Bennett F, Simms-Stewart D, Reid M, Williams NP, Wharfe GH et al. Cardiovascular disease risk factors in menopausal
Jamaican black women after hysterectomy and bilateral oophorectomy: an observational study. West Indian Med J 2010; 59: 625-32.

7. Cauley JA, Danielson ME, Gregg EW, Vogt MT, Zmuda J, Bauer DC. Calcaneal ultrasound attenuation in older African-American and Caucasian-American women. Osteoporosis International 1997; 7: 100-4. DOI: 10.1007/BF01623683

8. Grampp S, Genant HK, Mathur A, Lang P, Jergas M, Takada M et al. Comparisons of noninvasive bone mineral measurements in assessing age-related loss, fracture discrimination, and diagnostic classification. J Bone Miner Res 1997; 12: 697-711.

9. Gregg EW, Kriska A, Salamone M, Roberts LM, Aderson MM, Ferrell SJ et al. The epidemiology of quantitative ultrasound: a review of the relationships with bone mass, osteoporosis and fracture risk. Osteoporosis International 1997; 2: 89-99. DOI: $10.1007 / \mathrm{BF} 01623682$

10. Placide J, Martens MG. Comparing screening methods for osteoporosis. Curr Womens Health Rep 2003; 3: 20710.

11. Looker AC, Orwoll ES, Johnston CC Jr, Lindsay RL, Wahner HW, Dunn WL et al. Prevalence of low femoral bone density in older US adults from NHANES III. J Bone Miner Res 1997; 12: 1761-8.

12. Looker AC, Melton LJ 3rd, Harris TB, Borrud LG, Shepherd JA. Prevalence and trends in low femur bone density among older US adults: NHANES 2005-2006 compared with NHANES III. J Bone Miner Res 2010; 25: 64-71.

13. Looker AC, Johnston CC Jr, Wahner HW, Dunn WL, Calvo MS, Harris TB et al. Prevalence of low femoral bone density in older US women from NHANES III. J Bone Miner Res 1995; 10: 796-802.

14. Siris ES, Miller PD, Barrett-Connor E, Faulkner KG, Wehren LE, Abbott TA et al. Identification and fracture outcomes of undiagnosed low bone mineral density in postmenopausal women: results from the National Osteoporosis Risk Assessment . JAMA 2001; 286: 2815-22.

15. Siddle N, Sarrel P, Whitehead M. The effect of hysterectomy on the age at ovarian failure: identification of a subgroup of women with premature loss of ovarian function and literature review. Fertil Steril 1987; 47: 94-100.

16. Piver MS. Prophylactic oophorectomy: reducing the US death rate from epithelial ovarian cancer. A continuing debate. Oncologist 1996; 1: $326-30$.

17. Rocca WA, Grossardt BR, de Andrade M, Malkasian GD, Melton LJ 3rd. Survival patterns after oophorectomy in premenopausal women: a population-based cohort study. Lancet Oncol 2006; 7: 821-8.

18. Randell KM, Honkanen RJ, Tuppurainen MT, Kröger H, Jurvelin JS, Saarikoski S. Fracture risk and bone density of peri- and early postmenopausal women with uterine leiomyomas. Maturitas 2006; 53: 333-42. Epub 2005 Jul 12.

19. Kanis JA, Melton LJ, Christiansen C, Johnston CC, Khaltaev N. The diagnosis of osteoporosis. J Bone Miner Res 1994; 9: 1137-41.

20. Lips P. Epidemiology and predictors of fractures associated with osteoporosis. Am J Med 1997; 103: 3S-11S.

21. Alam NM, Archer JA, Lee E. Osteoporotic fragility fractures in African Americans: under-recognized and undertreated. J Natl Med Assoc 2004; 96: $1640-5$

22. Heinemann DF. Osteoporosis. An overview of the National Osteoporosis Foundation clinical practice guide. Geriatrics 2000; 55: 31-6; quiz 39.

23. McGuigan FE, Murray L, Gallagher A, Davey-Smith G, Neville CE, Van't Hof R et al. Genetic and environmental determinants of peak bone mass in young men and women. J Bone Miner Res 2002; 17: 1273-9.

24. Gibson TN, Hanchard B, Waugh N, McNaughton D. Age-specific incidence of cancer in Kingston and St Andrew, Jamaica, 2003-2007. West Indian Med J 2010; 59: 456-64. 